\title{
A New Financial Architecture For South American Countries
}

\author{
Pierre Canac (E-mail: canac@stthom.edu), University of St. Thomas
}

\begin{abstract}
Several South American countries experienced financial crises during the 1990 s and each responded differently. Thus Brazil floated the real following its 1997 crisis, Argentina started the decade with a currency board arrangement, but was forced to give it up some ten years later at more or less the same time that Ecuador adopted the dollar as its official currency. Chile, on the other hand, has been an island of financial stability in a subcontinent in turmoil. This article provides an alternative model for South American countries that could lead to more stability in the region and more independence from any of the major economies, especially the United States. This model borrows heavily from the experience of the European Union in general and European Monetary Union in particular. It recommends that the countries in South America first join a reformed Mercosur before forming a South American Monetary Union. In addition to creating a new common central bank or currency board, some other regional institutions will probably need to be created in order to coordinate economic policies, to negotiate with other countries, and to settle disputes that might arise among members.
\end{abstract}

\section{Introduction}

he decade of the 1990s was quite remarkable, characterized by strong economic growth in the U.S., decent economic performance in Europe leading to the birth of a new currency, the euro, and economic turmoil almost everywhere else. Japan is still struggling to extirpate itself from a decade-long slump, while various countries were subject to financial and banking crises: Mexico (1994), South East Asia (1997), Russia (1998), Brazil (1999), Turkey (2000), and Argentina (2001). Some of these crises, Turkey and Argentina for instance, are still evolving at the time of this writing. Financial markets have become increasingly volatile and subject to the overreaction of less than rational investors and speculators. Thus, between the beginning of 2002 and the election of Luiz Inacio "Lula" da Silva in Brazil on October 27, 2002, the real lost $40 \%$ of its value, thereby threatening the economy of the $11^{\text {th }}$ largest country in the world and the whole region.

This paper argues that Argentina, Brazil, and possibly some other South American countries constitute an Optimum Currency Area (OCA) and, therefore, should form a South American Monetary Union (SAMU) modeled on the European Monetary Union (EMU) ${ }^{1}$. In order to acquire the necessary credibility, the monetary policy of this South American Monetary Union could initially be implemented by a Currency Board Arrangement (CBA). However, it is argued that the common South American currency ${ }^{2}$, instead of being pegged to a single currency, could be pegged to a basket of currencies including possibly the dollar, the euro, and the yen. Such a system would provide limited but nevertheless critical bilateral exchange rate flexibility against any of the three reserve currencies without surrendering credibility, as the effective exchange rate of the common South American currency would be fixed against a basket of the three reserve currencies. In addition, this arrangement might foster both the economic and political integration of South America as well as preserve some element of sovereignty vis-a- vis each of the anchor countries.

The rest of the paper will be divided into three main parts. The first section focuses on the current weaknesses of the Mercosur. The second section explains why a currency board arrangement à la Argentinean is not

Readers with comments or questions are encouraged to contact the author via email. 
an appropriate financial system for the South American continent. The third section proposes the creation of a new financial architecture for South America that not only will remedy the weaknesses associated with the current monetary and financial system, but will also strengthen the cohesion among South American countries. Finally some concluding remarks close the paper.

\section{The Weaknesses of the Mercado Común del Sur (Mercosur)}

Mercosur was created in 1991 by the Treaty of Asuncion, although its origins date back to the Latin American Integration Association (1980). In 1988, Brazil and Argentina decided to further integrate their economies by eliminating their tariff barriers, harmonizing their macroeconomic policies, and establishing a common market with a common external tariff toward non-members. This new arrangement, which became known as Mercosur, also includes Paraguay and Uruguay. Chile and Bolivia became associate members in 1996 and 1997 respectively by signing a free trade agreement with Mercosur, and not adopting the common external tariff. The set of common external tariffs applies to approximately $90 \%$ of tradable goods and their levels range between 0 and 20 percent, with an average of $14 \%$. The ultimate objective of Mercosur is to create a common market by allowing the free mobility of all factors of production between its members, and to expand to include the Andean community ${ }^{3}$.

A regional trading arrangement (RTA), such as Mercosur, is operationally comparable to a bicycle; if it does not move forward, it collapses. Indeed, in recent years, Mercosur has actually reversed its progress. One of the reasons for this poor performance is the lack of a supranational institutional framework capable of forcing the two largest members, Brazil and Argentina, to abide by a common set of rules and coordinate their economic policies. Such a framework would allow the two countries to deal with their trade disputes instead of retaliating against each other's imposition of trade barriers. In a major instance of such retaliation, following the 1999 devaluation of the Brazilian real, some Argentinean firms protested that they could not compete against cheaper Brazilian imports and requested government protection. The Argentinean government responded by imposing import restrictions on Brazilian footwear, paper, pulp, and textiles. In addition, the appropriate institutions would allow the smaller countries, Uruguay and Paraguay, and also potential future members, to be heard by the two largest members. When there are significant disparities between the sizes of the members of a RTA, it is important that appropriate institutions are empowered to take the concerns of small countries into account. Under the existing arrangement, Uruguay and Paraguay periodically object to being dominated by Brazil and Argentina who have the tendency to reach bilateral policy agreements without consulting them.

Mercosur could learn a number of lessons from the example set by the European Union. For instance, the EU is currently discussing the reform of its institutions in preparation for the upcoming addition of ten Eastern and Central European countries in 2004. In order to accommodate these new entrants in such a way that they do not feel left out of the decision-making process, it is absolutely necessary to reform at least the European Commission and the Council. If the Mercosur countries do not create similar institutions, not only will the larger countries dominate the smaller ones, but the synchronization of macroeconomic policies among them will remain an illusory goal as individual countries will revert to pursuing beggar-thy-neighbor policies in their attempt to boost domestic growth.

\section{The Importance of a Well-Designed Financial Architecture}

During the 1990s, the economy of Argentina (and the other Mercosur members) was seriously damaged by the asymmetry of the existing currency board system. Here a few simple diagrams will be used to illustrate how asynchronous business cycles (possibly caused by occasional terms of trade shock) affect the money markets of the anchor country and its dollarized partner. Assume that we have two countries, the U.S. and Argentina, that their respective money markets are always in equilibrium, and that there is perfect capital mobility between them. This last assumption allows us to use the interest parity condition which can be written as $r_{\text {us }}=r_{\text {arg }}+\varepsilon$ where $r$ denotes the interest rates in the two countries, the U.S. and Argentina, and $\varepsilon$ is the expected rate of appreciation of the Argentinean peso vis a vis the U.S. dollar. Assuming that the peg is perfectly credible, then $\varepsilon=0$, and $r_{\text {us }}=r_{\text {arg }}$ as shown in Figure 1. 
Now suppose that Argentina is experiencing a negative terms of trade shock caused by the appreciation of the U.S. dollar against the currencies of Argentina's main trading partners, Brazil and the European Union. This, in turn, results in the peso being overvalued in terms of both the real and the euro, leading to a decline in Argentinean exports and a subsequent reduction in economic growth. Figure 1 below illustrates this scenario.

Figure 1

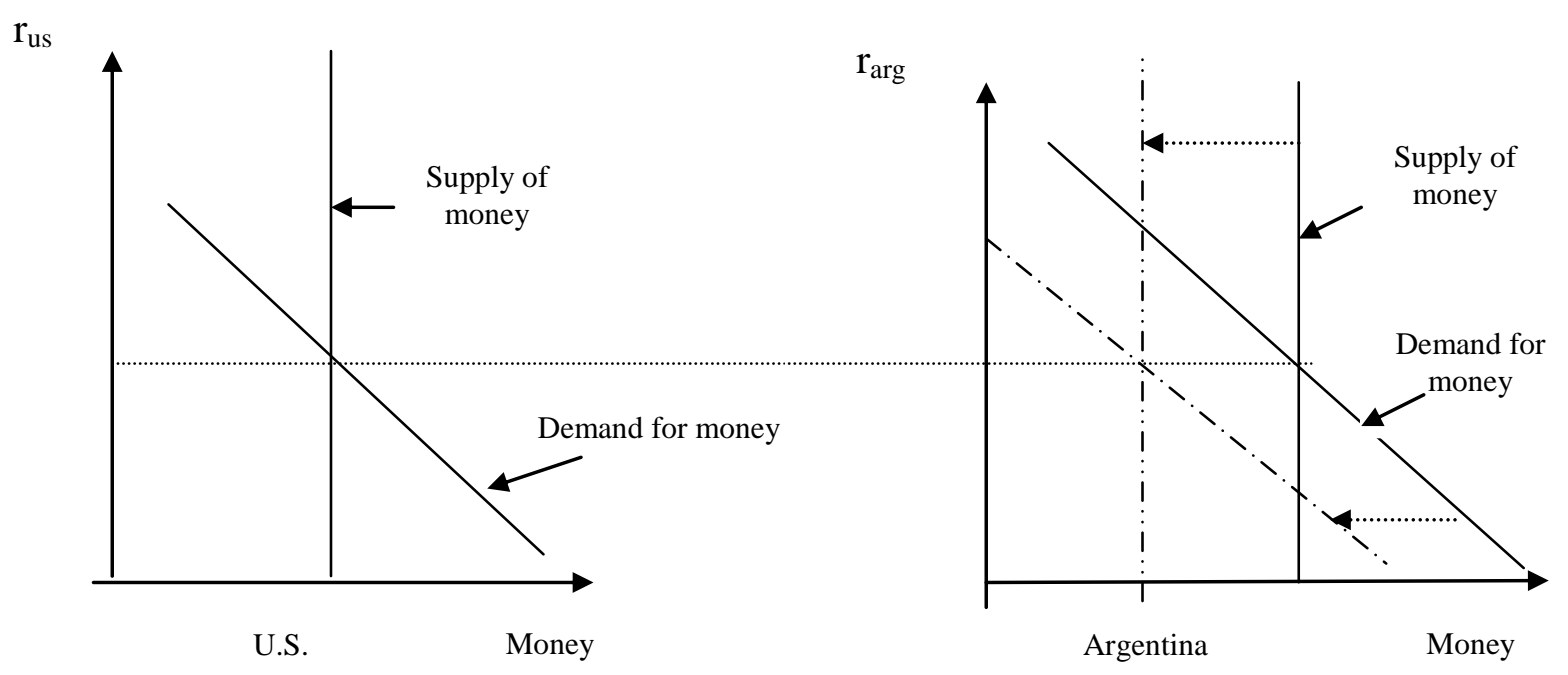

The recession in Argentina shifts the demand for money to the left in the rightward graph of figure 1. Assuming that no devaluation of the peso is expected, i.e. $\varepsilon=0$, (such an expected devaluation would only compound the problem), the Argentinean monetary authority must allow the money supply to fall in order to maintain both the same interest rate and exchange rate. The reduction in the money supply comes about as follows. As the demand for money falls in Argentina, we have an excess supply of money at the constant interest rate. The Argentinean monetary authority is forced to intervene by buying the excess pesos and selling dollars. In an asymmetric system, sterilization by the U.S. Federal Reserve will prevent the U.S. money supply from increasing. The entire burden of adjustment then falls on Argentina. Thus the recession in Argentina which originated with the terms of trade shock, is made worse by the ensuing forced contraction of its money stock.

If instead of the previous asymmetric system, there existed a symmetric system, the consequences of the negative terms of trade shock described above would be less severe for Argentina. In such a case, the U.S. monetary authority would let its money supply rise by not sterilizing the intervention of the Argentinean monetary authority. The money supply of the system as a whole would remain fixed instead of falling as in the asymmetric system, and the decrease in the Argentine money supply would be less severe. Figure 2 illustrates the symmetric response to the recessionary shock in Argentina.

This shows that an asymmetric monetary arrangement increases the severity of the recession in the peripheral country when the monetary authority of the dominant country has only domestic considerations in mind when setting its interest rate. In effect, the stable monetary policy in the U.S. makes the money stock of Argentina more volatile when unsynchronized business cycles occur. 
Figure 2

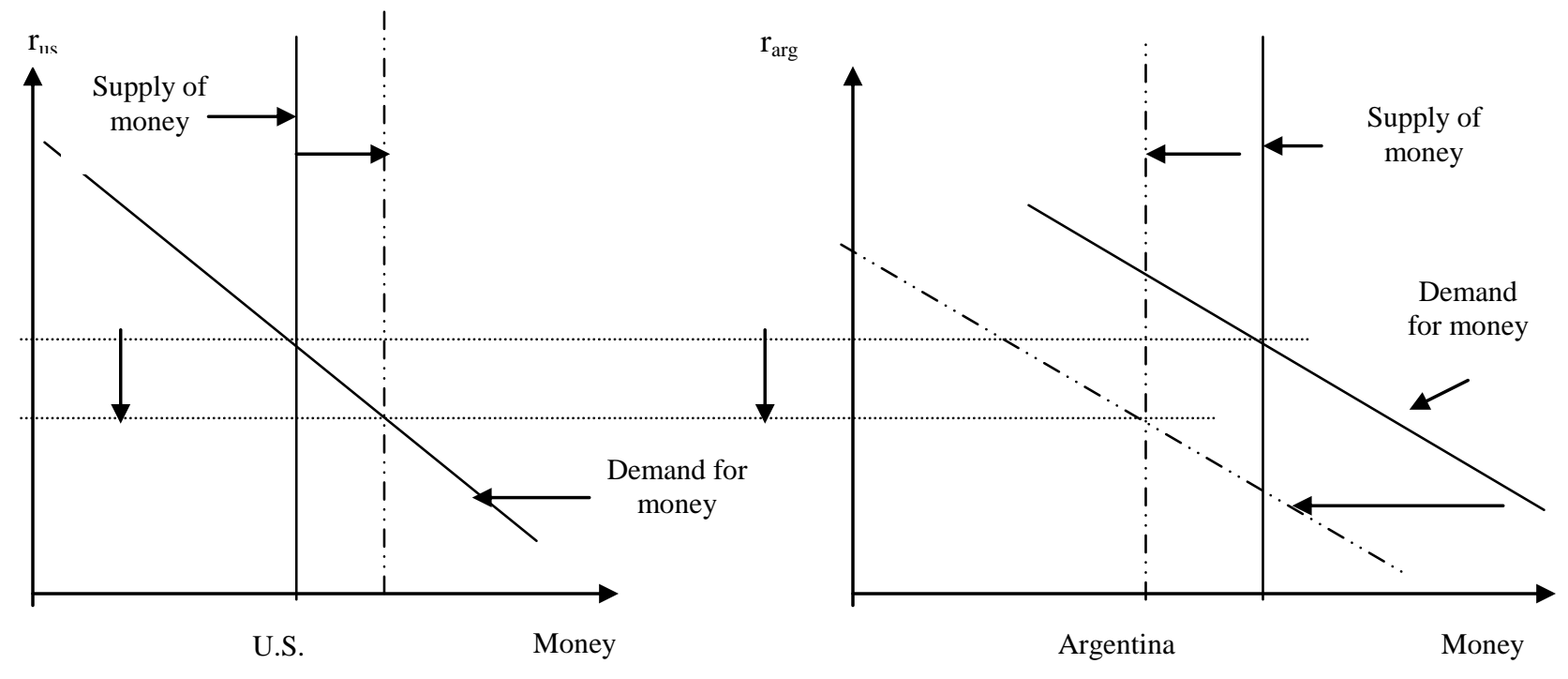

However the preferred symmetric solution (from the Argentinean perspective) would require that the Argentinean central bank governor have a seat on the Fed Open Market Committee (FOMC), an unthinkable outcome given the U.S. congress' exclusive concern in pursuing objectives that enhance only the national interests of the U.S. ${ }^{4}$ This leaves no choice to the Argentinean government, short of adopting a totally different system, but to suffer the consequences of the inefficient outcome resulting from the asymmetric financial arrangement. Such an alternative system will be described below.

\section{Proposals for Reform}

I will discuss two such proposals, one suggested by Domingo Cavallo during his short term as Argentina's finance minister in 2001, and another one that expands on Cavallo's proposal but has not been mentioned in the literature as far as I know. Before discussing these proposals, however, I will review briefly the theory of Optimum Currency Area.

Optimum Currency Areas (OCA) are groups of countries or regions that are closely linked by the trade of goods and services, by substantial financial flows, and by some degree of labor movement or labor market flexibility. The classic paper on OCA is Mundell (1967), and the theory has been somewhat refined since then as in Mongelli (2002). The theory predicts that countries that belong to a common OCA benefit by fixing their exchange rates or adopting a common currency. According to this theory, the countries that are likely to benefit the most from abandoning their currencies are those that satisfy the following characteristics:

1. A long history of high inflation, demonstrating a lack of credibility of the monetary authorities. This has certainly been the case in many Latin American countries, although the situation is currently much improved (see endnote \#7). High inflation is what pushed Ecuador to dollarize its economy in 2000.

2. A large volume of international trade with the anchor country. Although there is little doubt that the dollar would be the best anchor currency for Canada, Mexico, and most Central American countries, due to the high volume of trade and financial flows among them, this is probably not the case for Argentina and most South American countries. In fact, Argentina maintains a higher trade volume with both the EU and Brazil than with the U.S.

3. Business cycles that are highly correlated with that of the anchor country. In the absence of such synchronization, the monetary policy of the anchor country will not be appropriate for the dollarized 
economy. Unfortunately, while the U.S. economy has experienced a long period of economic growth in the 1990s and until the third quarter of 2001, Argentina has been in recession since the beginning of 1999 through 2002, and Brazil suffered a major financial crisis in 1997. The U.S. and most Latin American economies are so structurally different (the US is a commodity importer while many LA countries are mostly commodity exporters), that they are unlikely to react symmetrically to external shocks.

4. Prices in the dollarized country should be stable relative to those in the anchor country, otherwise the real exchange rate becomes overvalued. Moreover, if the rate of growth of productivity in the anchor country is higher than that of the dollarized country, then relative prices (including real wages) in the dollarized country will need to fall. Such necessary deflation will require the implementation of contractionary macroeconomic (i.e. fiscal) policies with the inevitable negative impact on economic growth.

In conclusion, one may doubt that Argentina and most other countries in South America belong to the same optimal currency area as the U.S. Therefore, the evidence strongly indicates that Argentina chose the wrong anchor currency. By appreciating against both the real and the euro, the dollar dragged the peso upward causing it to become overvalued in both nominal and real terms against these two currencies. Could it be instead that Argentina, Brazil, the remaining members of Mercosur, and other South American countries belong to the same OCA? In view of the fact that South American countries trade extensively with each other, have similar inflation rates, and show somewhat correlated business cycles, one could argue that this is indeed the case.

Moreover, even if these conditions are not entirely accurate, these countries could still form a monetary union if they had the political will and structure to cooperate, since the adoption of a common currency would force inflation rates, interest rates, and economic growth to converge, and facilitate the exchange of goods and services between all members. This, of course, would occasionally require individual member countries to sacrifice their individual interests to the common good, which would be challenging given their economic difficulties and lack of central authority, especially in matters of fiscal policy. In other words, the satisfaction of OCA properties is endogenous and will be a consequence of the formation of the monetary union ${ }^{5}$. Thus if South American countries were to decide to share a single currency and a common monetary policy, the two major economic/political issues to be solved are first, the designation of the anchor currency and second, the creation of a credible monetary authority for the monetary union. I will address these issues later after examining first a proposal made by the former Argentinean economic minister, Domingo Cavallo.

Cavallo's proposal is highly controversial--even more so than his previous proposal, the convertibility system that ended hyperinflation and ushered in a period of positive if mixed growth. When he was called back into service in 2001 by President Fernando de la Rúa to make the indebted and recessionary economy more competitive, he decided to tinker with his own creation. Both local and foreign investors, the main beneficiaries of the CBA, had questioned the wisdom of modifying the convertibility system. Nevertheless, Cavallo decided to go ahead by proposing to make the euro legal tender in addition to the dollar. One peso would become equal to half a dollar and half a euro. The table below compares the impact of a $40 \%$ appreciation of the dollar against the real and a $20 \%$ appreciation of the dollar against the euro, under both the previous convertibility system and the one proposed by Cavallo:

\begin{tabular}{|l|c|c|}
\hline Exchange rates & Previous system & Cavallo's proposal \\
\hline Value of peso in reais & $+40 \%$ & $+30 \%$ \\
\hline Value of peso in euro & $+20 \%$ & $+10 \%$ \\
\hline Value of peso in dollars & $0 \%$ & $-10 \%$ \\
\hline
\end{tabular}

As can be seen from these simple calculations, Argentina's loss of competitiveness would not have been as drastic under this proposal. As the dollar appreciates against both the real and the euro, the peso would not have appreciated as much against these two currencies under this modified CBA. In addition, the peso would have depreciated a little (10\%) against the dollar. Overall, Argentina's effective exchange rate would have been more stable and its terms of trade would not have deteriorated as much. The peso would still be anchored, but instead of 
one fixed anchor (the dollar), it would have two floating anchors (the dollar and the euro), and as all sailors know, floating anchors work better in stormy weather! However, this may only be a second best solution.

The following proposal could be called a currency board on top of a common currency for lack of a better term. In such a set up, the monetary policy of the countries which belong to the same optimum currency area would be regulated by a currency board instead of a central bank. However, instead of the common currency being pegged to only one anchor currency, it would be pegged to a basked of possibly two or three reserve currencies. The economies of the Mercosur members (including potential members, Chile, Bolivia, Peru, Ecuador, and Colombia) being structurally similar, are likely to face symmetric external shocks. ${ }^{6}$ Their business cycles are thus more likely to be synchronized making these South American countries good candidates for establishing a monetary union, provided that the system is so designed that the monetary authority of the union is a credible institution. To establish such credibility, the countries would have to phase in their system in a series of logical steps. Initially, Mercosur members must agree on a set of preconditions, somewhat similar to those specified in the Maastrich treaty, to be fulfilled before adopting a common currency issued by a South American monetary institution. Any South American country that is a member of Mercosur and satisfies these same preconditions would be invited to join. Thus membership to Mercosur, which would be open to all countries in the region, would be a precondition for eligibility to join the monetary union. Such steps would contribute greatly to fostering the economic and political integration of South American countries. Rose (2000) has found that there is a large positive effect of a currency union on international trade. He estimates that two countries sharing the same currency trade three times as much as they would under separate currencies. Such an increase in trade could also affect the sustainability of the monetary union itself. Frankel and Rose (1998) have shown that increased trade between countries is associated with more synchronized business cycles, making the monetary union more sustainable. Thus, while a devaluation (i.e. the 1999 devaluation of the real) may destroy a customs union by compelling a trade partner to use protective tariffs (Cavallo's 2001 competitiveness law), the formation of a monetary union, by increasing the volume of trade between members, may instead strengthen a customs union. Then as the business cycles of customs union members become more highly correlated, the monetary union gains in strength. As a result, the member nations would replace vicious cycles with virtuous ones.

In order for this South American monetary institution to be immediately credible, I propose the creation of a South American currency board rather than a central bank. Also desirable would be the added option of transforming the currency board into a full-fledged central bank down the road once the experiment has proven successful and credibility has been achieved. Such a currency board would hold multiple reserve currencies (as in Cavallo's proposal above), the dollar, the euro, and possibly the yen, with weights reflecting the volumes of trade with the corresponding three regions of the world (instead of 50\% for the dollar, 50\% for the euro, and 0\% for the yen, as in Cavallo's initial proposal). Such a system would allow the largest economic gains from integration and would prevent political dominance by one of the reserve countries. In addition to the South American currency board, other common institutions will have to be created to accomplish certain shared aspirations such as resolution of trade disputes, sustaining competition, coordinating fiscal policies (including the possible transfer of funds between countries), and negotiating trade agreements with other regions of the world, including the creation of a FTAA.

Alternatively, it is also possible that the creation of a South American currency board may not be necessary. Given that several Latin American countries have demonstrated that they are capable of maintaining low inflation rates under flexible exchange rate systems (i.e. Chile, Mexico, and Brazil) ${ }^{7}$, it is easy to imagine that a South American central bank would be able to achieve low inflation rates. We know that a central bank free from political interference is a necessary, although not sufficient, condition to insure price stability. Latin Americans certainly have the expertise required to run an independent central bank.

\section{Concluding Remarks}

An important concept in International Finance is known as "the impossible trilogy." According to this concept, it is not feasible for a country to simultaneously have a fixed exchange rate system, perfect capital mobility and an independent monetary policy. In theory, only two out of three of these conditions are possible. However, in 
practice, even achievement of two of these conditions is unlikely. For example, it is doubtful that a small open economy will be able to follow an independent monetary policy, even under a flexible exchange rate system. Faced by a sudden unexpected capital outflow, a small country would have to drastically increase its interest rate in order to prevent its currency from collapsing. Thus under a flexible exchange rate system (and perfect capital mobility), a small, open economy will experience very volatile interest rates and will have very little control over them. The key element is that most developing countries are starved for foreign savings. Without access to foreign savings, they will simply be unable to develop and grow. This certainly applies to most Latin American countries. In the 1990s, many of these countries adopted some form of dollarization in order to attract capital inflows. This was the case for Argentina in 1991 and Ecuador in 2000. However, as we all know, the Argentinean experience ended abruptly in 2001 when the combination of overvaluation of its currency and large foreign debt caused investors to lose confidence in the sustainability of the peg leading to capital outflows and the collapse of the economy. If the long run sustainability of dollarization in South America is questionable at best, and if a totally flexible exchange rate does not guarantee relatively stable interest rates due to the small size of most of these countries (relative to the U.S.) and the prevalence of capital mobility, a new financial architecture for South America should be seriously considered as a possible option.

In this paper, I have attempted to show that uncooperative unilateral forms of monetary union (i.e. dollarization) are inferior to the multilateral and cooperative form of monetary union such as the European Monetary Union. I have argued this by subjecting the economies of Latin America to economic analysis, indicating how they would fare under alternative monetary arrangements. In addition, I believe that the strong trend toward official dollarization in America is a response to the demands of that powerful system of norms and principles that ties Latin America to the dollar. It is not the result of a cost-benefit calculus carried out by Latin America's policymakers. The determinants of exchange rate regimes are political, and they reflect those countries' subservient position in the international monetary system dominated by the U.S. for its benefit.

It is clear that countries in South America will require capital inflows for many years to come. Nevertheless, it is imperative that these countries, as members of a stronger, larger, more disciplined, and more credible trade and monetary union, start diversifying their sources of foreign savings in order to reduce their dependence on the dollar and the U.S. Such a set up would not necessarily preclude the occasional occurrence of destabilizing capital flight, but could possibly make such event less likely in the future. So far, it seems that their strategies to gain access to the necessary large pools of dollars has required the occurrence of periodic foreign exchange crises. In other words, as soon as a foreign exchange crisis occurs and private capital inflows are reversed, the IMF and the U.S. treasury rush some kind of conditional rescue package to stop the hemorrhage. Although this strategy has somewhat achieved its objective of providing capital to Latin American countries, it has increased their dependence on the U.S. and international financial institutions, and caused a pattern of burst and boom cycles which are incompatible with steady economic growth and improved social conditions.

If a majority of South American countries were to decide to form a South American Monetary Union, they would be able to reclaim co-ownership and co-management of their monetary asset, their common currency, in a multilateral monetary union with like-minded countries. It will be critical that the central bank of the union be independent of the member countries' political authority, and respond to the needs of the union rather than those of its largest members. The Europeans have demonstrated that this can be done in spite of the vast differences in the economic levels of some Eurozone members such as Germany and Greece. Even though the ECB is a young institution, it is not a weak one, and the euro is now a strong currency ${ }^{8}$ successfully competing with the dollar to occupy its place as one of the main reserve currencies. To prevent the value of a national monetary asset from being ruined by mismanagement, a South American currency board could be created instead of a central bank. To ensure that this currency board is not dominated by the U.S., the value of the new currency could be pegged to a basked to two or more reserve currencies, with weights determined by the trade volumes between South America and the various anchor countries. Eventually, this multi-country currency board could become a full-fledged central bank as soon as it has gained sufficient credibility and reputation.

One important side benefit of institutional reform would be to increase the cohesiveness of all the countries in the region as they would be required to coordinate not only their monetary policy but also their fiscal policy as the 
imprudent fiscal policy of one of the members could have negative effects on the whole union and undermine the common currency. Again, the successes as well as the failures (i.e. the growth and stability pact) of the Europeans could be used as a blueprint after being modified to fit the South American context.

Only one element appears to be missing: the political will among South American countries to form such a monetary architecture and create the centralized political structure that must induce the deeper economic integration of these countries. Clearly, the U.S. will not look favorably upon this system, as it will lessen its dominance of the Western hemisphere (its backyard?). On the other hand, I am confident that the Europeans, if asked, would be enthusiastic about providing support and advice for such an undertaking.

\section{References}

1. Baer, Werner, Pedro Elosegui, and Andres Gallo (2002), "The Achievements and Failures of Argentina's Neo-liberal Economic Policies", Oxford Development Studies 30 (1).

2. Barro, Robert J. (12/11/2000), "The Dollar Club: Why Countries are so Keen to Join", Business Week 3711: 34.

3. Beddoes, Zanny Minton (1999), "From EMU to AMU? The Case for Regional Currencies", Foreign Affairs 78 (4): 8-13.

4. Berg, Andrew, and Eduardo Borensztein (2000), "The Dollarization Debate", Finance \& Development 37 (1): $38-41$.

5. $\quad$ Bogetic, Zeljko (2000), "Full Dollarization: Fad or Future?” Challenge 43 (2): 17-48

6. Calcagno, Alfredo, and Sandra Manuelito (2001), "Argentine Convertibility: Is It a Relevant Precedent for the Dollarization Process in Ecuador?" UN Economic Commission for Latin America and the Carribean (ECLAC) Estudios Estadisticos y Prospectivos 15.

7. Calvo, Guillermo, and Carmen M. Reinhart (1999), "Capital flow reversals, the exchange rate debate, and dollarization", Finance \& Development 36(3): 13-15.

8. $\quad$ Chang, Roberto (2000), "Dollarization: A Scorecard." Federal Reserve Bank of Atlanta Economic Review 85 (Third Quarter): 1-11.

9. Chriszt, Michael (2000:4), "Perspectives on a Potential North American Monetary Union", Federal Reserve Bank of Atlanta Economic Review 85 (4): 29-38.

10. Cohen, Benjamin (2002), "U.S. Policy on Dollarization: A Political Analysis", Geopolitics 7 (1): 63-84.

11. Fischer, Stanley (1982), "Seigniorage and the Case for a National Money." Journal of Political Economy 90 (April): 295-313.

12. Francis, David (12/18/2000), "Latin America Tightens its Ties to the Greenback", Christian Science Monitor 93 (17): 17

13. Frankel, J. A. (1999), "No Single Currency Regime is Right for all Countries or at all Times", Essays in International Finance, Princeton University (August).

14. Frankel, J. A. and S. J. Wei (1998), "Trade Blocs and Currency Blocs”, NBER Working Paper No. 4335.

15. Frankel, J. A. and Andrew K. Rose (1997), "The Endogeneity of the Optimum Currency Area Criteria", Center for Economic Policy Research Discussion Paper Series No. 1473.

16. Gajewski, Joanna (2001), “The Greenback Effect”, World Link (May/June):28-33

17. Grubel, Herbert (1999), "The Case for the Amero: The Economics and Politics of a North American Monetary Union." The Simon Fraser Institute Critical Issues Bulletin, September.

18. Hanke, Steve H., and Kurt Schuler (1999) "A Monetary Constitution for Argentina: Rules for Dollarization." CATO Journal 18 (Winter): 405-20.

19. Hausmann, Ricardo (1999), "Should There Be Five Currencies or One Hundred and Five?" Foreign Policy 116 (Fall): 65-79.

20. Howe, Benjamin Ryder (2001), "Getting Used to the Greenback", Atlantic Monthly 287 (5): 23-26.

21. Jameson, Kenneth P. (2001), "Latin America and the Dollar Bloc in the Twenty-first Century: To Dollarize or Not?" Latin American Politics and Society 43 (4): 1-37.

22. Mundell, Robert (1961), "A Theory of Optimum Currency Areas." American Economic Review 51:657-65.

23. Mongelli, Francesco Paolo (2002), "'New' Views on the Optimum Currency Area Theory: What is EMU Telling us?” European Central Bank Working Paper 138 (April). 
24. Rose, Andrew (2000), "One Money, One Market: Estimating the Effects of Common Currencies on Trade", Economic Policy 30: 9-45.

25. Ritter, Archibald, and Nicholas Rowe (2002), "Cuba: From Dollarization to Euroization or Peso Reconsolidation?” Latin American Politics and Society, 44 (2): 99-123.

26. Sachs, Jeffrey, and Felipe Larrain (1999), "Why Dollarization Is More Straitjacket Than Salvation", Foreign Policy 116 (Fall): 80-92

27. Schorr, Daniel (2001), "Cuba Revisited", New Leader 84 (3): 5

28. Schuler, Kurt (1999), "Encouraging Official Dollarization in Emerging Markets." Staff Report, Joint Economic Committee (Office of the Chairman), U.S. Congress, April.

29. Taylor, Alan M. (2000), "Dollarization as a Technology Import", FRBSF Economic Letter 2000 (16): 1-3.

30. Velde, Francois R., and Marcelo Veracierto (2000), "Dollarization in Argentina", Economic Perspectives 24 (1): 24-37.

31. Von Furstenberg, George (2000), “A Case Against Dollarization”, Challenge 43(4): 108-120

\section{Endnotes}

${ }^{1}$ Beddoes (1999) argues that by 2030 the world will have only two major currencies, the dollar and the euro and that most countries will either belong to the EMU (European Monetary Union) or to a future AMU (American Monetary Union). Grubel (1999) and Chriszt (2000) talk only about a more modest proposal whereby, the U.S., Canada, and Mexico would join a NAMU (North American Monetary Union). This paper, on the other hand, argues that most South American countries should join a SAMU (South American Monetary Union).

${ }^{2}$ Some names that have been mentioned in the literature for a new currency are Amero and Gaucho. However, amero has been mentioned in the context of a possible new common currency for the U.S., Canada, and Mexico, while gaucho might not be acceptable to Brazil because of its Argentinean association. In view of the fact that it is unlikely that the U.S. will ever abandon its dollar, the name amero might conceivably be preferred by the South American countries.

${ }^{3}$ The Andean Community includes the following countries: Colombia, Bolivia, Ecuador, Peru, and Venezuela. Chile did not join Mercosur as the CET, $14 \%$ on average, was higher than most of Chile's current tariffs. Thus Chile would have had higher tariffs in Mercosur than out of it.

${ }^{4}$ The International Monetary Stability Act of 1999, S.1879, introduced November 8,1999, and referred to the Senate Committee on Banking, Housing, and Urban Affairs, indicates for the first time that the U.S. Congress could be willing actively to encourage dollarization. The act recognizes that official dollarization of the Western Hemisphere imposes significant costs on the economies of the dollarizing countries, and that it was logical to compensate such countries in order to improve their chance of economic success. However, the act stresses that the Federal Reserve System has no obligation to act as lender of last resort or to consider the economic conditions of dollarized countries when formulating or implementing U.S. monetary policy. It only offers partial conditional compensation for the loss of seignorage by the dollarizing country. Unfortunately, the act was not approved by Congress.

${ }^{5}$ Frankel (1999), Frankel and Wei (1998), and Frankel and Rose (1997) show that both the degree of openness and the correlation of incomes increase among countries sharing a single currency and a common monetary policy. Thus the satisfaction of OCA properties is endogenous, implying that even if countries do not satisfy OCA properties ex ante they may satisfy them ex post.

${ }^{6}$ Eventually the countries that would adopt the common South American currency would be the four members of Mercosur (Brazil, Argentina, Uruguay, and Paraguay), the five members of the Andean Community (Bolivia, Colombia, Ecuador, Peru, and Venezuela), and Chile. Of these ten countries, only Ecuador has a dollarized economy and would be required to abandon the dollar to adopt the new currency.

${ }^{7}$ The inflation rate in Brazil fell to 1.14\% in March from 1.57\% in February and 2.25\% in January. Although the government target of $8.5 \%$ for 2003 may be hard to achieve, it is clear that the numbers are moving in the right 
direction. The previous jump in inflation had been caused by a depreciating currency during the time surrounding the election of Luiz Inacio Lula da Silva. Similarly, in Argentina, the inflation rate is falling after a huge upward jump following the $70 \%$ devaluation of the peso. The Economy minister, Roberto Lavagna, forecasts an inflation rate of $18 \%$ in 2003 compared with last year's rate of $40 \%$. Moreover, the Argentinean economy is growing again in early 2003 after contracting by some $13 \%$ in 2002, thanks to a weaker peso and growing exports. Chile, Mexico, Peru, and Colombia have also relatively low inflation rates of $4.5 \%, 5 \%, 3.5 \%$, and $7.5 \%$ respectively. This clearly demonstrates that Latin American countries are able to maintain low inflation rates even without the discipline forced upon them by a fixed exchange rate system.

${ }^{8}$ At the time of this writing (April 2003), after its recent gain against the dollar, the euro is worth about $\$ 1.10$.

Notes 